\title{
RESEARCH ARTICLE \\ Molecular Characterization of Caulerpa racemosa (Caulerpales, Chlorophyta) from Indonesia Based on the Plastid tufA Gene
}

\author{
Muhamad Darmawan ${ }^{1,3^{*}}$ Neviaty Putri Zamani², Hari Eko Irianto ${ }^{3}$, and Hawis Madduppa ${ }^{2}$
}

OPEN ACCESS

${ }^{1}$ Graduate School of Marine Sciences, IPB University, Bogor, Indonesia, 16680

${ }^{2}$ Department of Marine Science and Technology, IPB University JI. Rasamala, Kampus IPB Darmaga, Bogor, Indonesia 16680

${ }^{3}$ Research Center for Marine and Fisheries Product Processing and Biotechnology, JI. KS Tubun Petamburan VI, Jakarta, Indonesia 10260

* Corresponding Author:

muhamad.darmawan@kkp.go.id

m.darmawan22@gmail.com

Received: 30 July 2021

Accepted: 26 November 2021

Published: 17 December 2021

- Squalen Bulletin of Marine and Fisheries Postharvest and Biotechnology, 2021. Accreditation Number: 148/M/KPT/2020. ISSN: 2089-5690, e-ISSN: 2406-9272. doi: 10.15578 /squalen. 588

\begin{abstract}
The green seaweed Caulerpa racemosa is a seaweed of high prospect that is being given emphasis by the Indonesian government. However, C. racemosa in Indonesia may include multiple species level-entity exhibiting morphological overlap and require molecular analysis for species identification. Molecular documentation of species richness of indigenous populations of $C$. racemosa is essential to underpin cultivar development and conservation of the species to avoid overharvesting. The present study aimed to determine the genetic diversity of $C$. racemosa and document the haplotype network of the specimens from four different locations (Bintan Island, Jepara, Takalar and Osi Island) using the chloroplast tufA gene. Twenty individuals from four areas were collected and amplified with the chloroplast-encoded gene tufA for species identification against publicly available data. The identification of $C$. racemosa based on the tufA gene showed that the species found in four locations were $C$. cylindracea (previously $C$. racemosa var. cylindracea), C. macra (previously $C$. racemosa var. macra), $C$. racemosa, and $C$. oligophylla (previously $C$. racemosa var. lamourouxii). This study records the existence of $C$. cylindracea in Takalar and Jepara, Indonesia for the first time. The most diverse $C$. racemosa species was in Osi Island, where the exploitation of this seaweed is very low. In contrast, the lowest number of $C$. racemosa varieties were found in Takalar, where exploitation is very high. There were only minor light variations of Caulerpa species in the tufA gene in four different sites with only four haplotypes found, and each haplotype corresponded to another species.

Keywords: genetic diversity, haplotype, Caulerpa macra, Caulerpa oligophylla, Caulerpa cylindracea
\end{abstract}

\section{I ntroduction}

Caulerpa is one of the most widely distributed marine green algae in the tropical and warm-temperate seas (Draisma et al., 2014; Rushdi et al., 2020; Darmawan, Fajarningsih, Sihono, \& Irianto, 2020). The genus of Caulerpa currently consists of 174 recognized species (Guiry \& Guiry, 2021), many of which are associated with an exceptional capacity to adapt to a wide range of environmental factors such as temperature, depth, irradiance, and substrates. As such, Caulerpa can be found from the intertidal to subtidal zones (Baleta \& Nalleb, 2016).

Caulerpa is a multinucleate siphonous green alga that differs from other coenocytic green algae, in a way that it has a trabeculae, or cell wall ingrowths that creates an anastomosing network for structural support (Zubia, Draisma, Morrissey, Varela-Álvarez, \& De Clerck,
2020). The plants in the genus Caulerpa have the same basic morphological structure, which consists of rhizophores, stolon, and fronds (assimilators) (Manas et al., 2015; Zubia et al., 2020). The rhizophores of Caulerpa attach to rigid substrate or anchor to the unconsolidated substrate. The shape of stolon can be different from one species to another, such as smooth (glabrous) or covered in scale-like appendages (squamiferous). The fronds (assimilators) stand upright from the stolon. It has a branchlet (ramuli) with various arrangements and shapes (Zubia et al., 2020). The differences in gross morphology of fronds, stolons, and rhizoids and the form and size of ramuli were used to identify most species (Manas et al., 2015).

Some species of the genus Caulerpa are economically important because they can be sold in the local and international markets. Compared to Gracilaria, Eucheuma, and Sargassum, the production 
of Caulerpa seaweed for the international trade is very small (less than $0.5 \%$ ) from the total seaweed trade globally (Zubia et al., 2020). Caulerpa's two different species from the genus Caulerpa with a significant economic value are $C$. racemosa and $C$. lentilifera (Estrada, Bautista, \& Dionisio-Sese, 2020). C. racemosa has a bigger vesiculate branchlet and is often called sea grapes or grape algae. In comparison, $C$. lentilifera has a smaller vesiculate branchlet and is usually called green caviar (Zubia et al., 2020). C. lentillifera has ramuli with globose tips constricted at the base and arranged imbricated in four rows. In contrast, $C$. racemosa has highly variable ramuli, can be stipitate or substipitate, and arranged irregularly distichous, multiseriate, or imbricate (Estrada et al., 2020).

Seaweeds are known for their phenotypic plasticity, which means the same species of seaweeds can exhibit morphological variations under different environmental conditions (Estrada et al., 2020). Like other seaweed species, $C$. racemosa has a high level of phenotypic plasticity, making it one of the most taxonomically problematic species (Fama, Procaccini, Olsen, \& Stam, 2000; Belton et al., 2014; Estrada et al., 2020; Zubia et al., 2020). Taxonomic issues associated with phenotypic plasticity has been reported in many algal groups (Sauvage et al., 2013; Dumilag et al., 2018; Belton et al., 2019; Ningrum \& Chasani, 2021). The phenotypic plasticity can lead to misidentifications, nomenclatural quagmires, incorrect biodiversity estimates, and confusing classification schemes (Belton et al., 2014). Many of these issues have since been elucidated or resolved with the advance of molecular identification and characterization techniques.

The correct identification and characterization of seaweed species are essential to overcoming the taxonomic ambiguity of seaweed species, especially for those with economic interests. The growth factor and biochemical compounds can be differentiated and measured between areas and across the environmental condition. In Indonesia, the molecular identification of local seaweed has only been sporadically employed (Zuccarello \& Paul, 2019). The advent of molecular tools has provided researchers with an independent and convenient method to delimit and identify species in taxonomically challenging groups (Belton et al., 2014). In recent years, the use of molecular identification techniques has improved our understanding of the biodiversity of Caulerpa (Fama et al., 2000; Žuljeviæ et al., 2003; Dumilag et al., 2019; Wynne, Verbruggen, \& Angel, 2009; Sauvage, Wynne, Paul, \& Fredericq, 2014). Today, species discrimination in Caulerpa is generally based on several genomic loci, with the chloroplast gene tufA being used almost universally (de Senerpont Dormis et al., 2003; Kazi, Reddy, \& Jha, 2013; Sauvage et al., 2013; Belton, Prud'homme Van Reine, Huisman, Draisma, \& Gurgel, 2014; Belton, Draisma, Prud'homme van Reine, Huisman, \& Gurgel, 2019; Dumilag et al., 2019).

The majority of the islands of Indonesia are located within the Coral Triangle, which is a hotspot for marine flora and fauna. This region, western tropical Atlantic, and Australia's southern coast (Sauvage et al., 2013) have been identified as areas with a high diversity of Caulerpa. Despite this, the molecular characterization of $C$. racemosa in Indonesia remains poor. Although morphological identification has identified 32 species of Caulerpa from the western to eastern parts of Indonesia, including 11 different morphotypes of $C$. racemosa (Atmadja \& Prud' homme van Reine, 2014), these were not supplemented with genetic data. Owing to the commercial importance of Caulerpa in the international market, the Indonesian government has developed strategies to strengthen the country's position in the seaweed market (Ministry of Marine Affairs and Fisheries, 2017). The complete information about species richness and genetic biodiversity in Indonesia is essential to anticipate the overexploitation of $C$. racemosa in the future and obtain new strains to improve varieties with more desirable characteristics through tissue culture. Despite the biodiversity assessment, genetic diversity research is essential for exploiting and conserving C. racemosa. This study aimed to identify specimens of $C$. racemosa from Bintan Island, Jepara, Takalar, and Osi Island, Indonesia, using the tufA DNA barcode and determining the haplotype network of the specimens in these locations.

\section{Materials and Methods}

\section{Sample Collection}

C. racemosa were collected from October 2018 September 2019 at four different locations from the western to the eastern part of Indonesian waters. The sampling locations were Bintan Island (Riau Islands), Jepara (Central Java), Takalar (South Sulawesi), and Osi Island (Maluku) (Figure 1). Five specimens were collected from each site. The samples of $C$. racemosa, attached to the substrates, were collected from the subtidal zone. Individuals collected were at least $10 \mathrm{~m}$ apart to avoid the collection of ramets. Individuals were cleaned using seawater and desiccated using silica gel with a sample:silica gel ratio of 1:10. Samples were transferred to the laboratory for molecular analysis. 


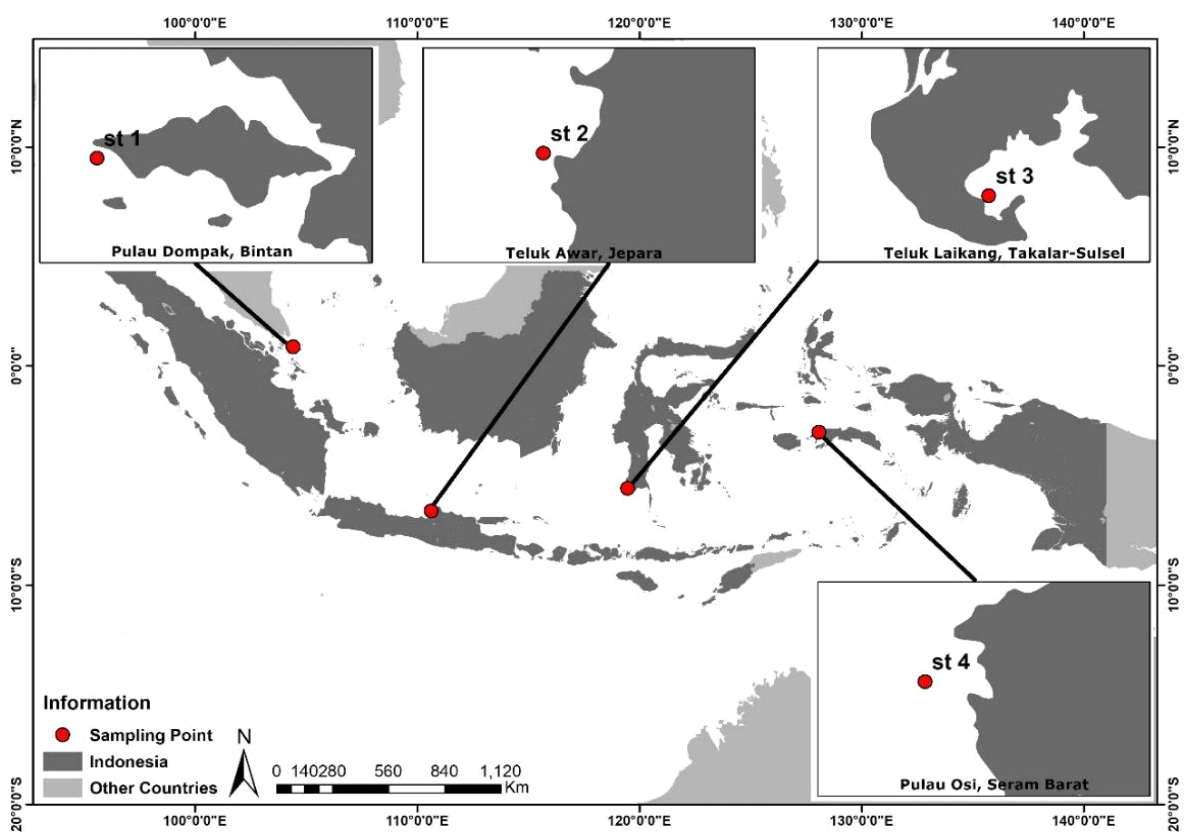

Figure 1. Map showing sampling locations.

DNA Extraction, Amplification, and DNA Sequencing

All dried algal samples were extracted using the cetyltrimethylammonium bromide (CTAB) method (Zuccarello \& Lockhorst, 2005; Zuccarello \& Paul, 2019). A microcentrifuge tube containing $500 \mu \mathrm{L}$ of CTAB extraction buffer (2\% CTAB, $0.1 \mathrm{M}$ Tris- $\mathrm{HCl}$ with pH 8, 1.4 M NaCl, 20 mM EDTA, 1\% PEG 8000) plus $50 \mu \mathrm{g}$ RNAse A and $80 \mu \mathrm{g}$ Proteinase K (Promega, Madison, USA) was used to place the sample. The samples were ground and homogenized with a microcentrifuge pestle. Samples were then heated to $55-60{ }^{\circ} \mathrm{C}$ for $30 \mathrm{~min}$ and mixed occasionally. An equal volume of the solution consists of chloroform:isoamyl alcohol (24:1) was added to the samples. Samples then spun at 12,000 rpm for 5-10 min. The aqueous phase was then extracted with an equal volume of chloroform: isoamyl alcohol (24:1), spun for $5 \mathrm{~min}$ at 12,000 rpm and removed to a new tube. An equal volume of $100 \%$ isopropanol was added to the samples. The tube was inverted occasionally and placed at room temperature for $30 \mathrm{~min}$. The samples were spun for $30 \mathrm{~min}$ at 12,000 $\mathrm{rpm}$ and decanted. The DNA pellet was washed in $70 \%$ ethanol, air-dried, and $50 \mu \mathrm{L}$ of $0.1 \times \mathrm{TE}$ buffer was added. The sample was then frozen $\left(-20^{\circ} \mathrm{C}\right)$ until use.

Polymerase Chain Reaction (PCR) amplification was performed in a master mix of $25 \mu \mathrm{L}$ containing $1.5 \mu \mathrm{L}$ of tufA forward primer (DNA sequence of forwarding PCR primer), and $1.5 \mu \mathrm{L}$ of tufA reverse primer (5'TGAAAC AGA AMA WCG TCA TTA TGC CCT TCN CGA ATM GCR AAW CGC 3') (Kazi et al.,
2013), $12.5 \mu \mathrm{L}$ KOD FX Neo buffer (Toyobo, Japan), $5 \mu \mathrm{L} 2 \mathrm{mM}$ dNTP, $0.5 \mu \mathrm{L}$ KOD FX Neo (Toyobo), and $4.5 \mu \mathrm{LPCR}$ water. PCR amplification conditions involve an initial denaturing step at $94^{\circ} \mathrm{C}$ for 3-5 min; followed by 10 cycles of $94{ }^{\circ} \mathrm{C}$ for $30 \mathrm{~s}, 55^{\circ} \mathrm{C}$ for $1 \mathrm{~min}$, which is reduced by $1{ }^{\circ} \mathrm{C}$ per cycle, and $72{ }^{\circ} \mathrm{C}$ for $30-60 \mathrm{~s}$; followed by 25 cycles of $94{ }^{\circ} \mathrm{C} / 30 \mathrm{~s}, 45^{\circ} \mathrm{C} / 30 \mathrm{~s}, 72{ }^{\circ} \mathrm{C}$ $130 \mathrm{~s}$; and a final extension of $72{ }^{\circ} \mathrm{C}$ for $5 \mathrm{~min}$ (Zuccarello \& Paul, 2019). Amplification was verified based on a $1 \%$ agarose gel electrophoresis. Samples were purified, and Sanger sequenced at $1^{\text {st }}$ Base Laboratories (Malaysia).

\section{Phylogenetic and Haplotype Network}

The phylogenetic reconstruction was built using the 20 samples, which were sequenced in both directions. All samples were edited, trimmed to equal length, and extracted to an alignment in MEGA 6 (Tamura, Stecher, Peterson, Filipski, \& Kumar, 2013). TufA sequences from various C. racemosa with 41 sequences were downloaded from National Center of Bioinformatics Institute (NCBI), edited, and added to the sample's alignments. A sequence of Caulerpella ambigua (GenBank Accession Number AJ417963) was added to the alignment and used as an outgroup. The multiple-sequence alignment (MSA) was performed to have a final alignment that is more suitable for the phylogenetic analysis (Castresana, 2000). The MSA was created using the Clustal IW (Thompson, Higgins, \& Gibson, 1994) and then optimized visually. Sequence similarity searches were conducted for all samples against representative Caulerpa species from the 
database in National Centre for Biotechnology Information (NCBI) using the Basic Local Alignment Search Tool (BLAST) (http://www.ncbi.nlm.nih.gov). The species identification followed Belton et al. (2014) for a naming system based on reinstated epithets. A phylogenetic tree (maximum-likelihood) was constructed based on the General Time Reversible model with 1000 bootstrap replicates using MEGA 6 (Nei \& Kumar, 2000).

A haplotype network using $20 \mathrm{C}$. racemosa from four sites in Indonesia was calculated using the Median Joining method implemented in Network v5.0 (Bandelt, Forster \& Rohl, 1999). The connectivity of $C$. racemosa was analyzed to determine the connection of the genetic compositions in each site. The names of species in each location were provided in a proper map to show a clear, transparent precise distribution among populations.

\section{Results and Discussion}

\section{Phylogenetic}

Twenty sequences of $741 \mathrm{bp}$ fragments of chloroplast tufA gene of $C$. racemosa were obtained from four sampling sites across the Indonesian archipelago. The result of Caulerpa species identification is shown in Table 1. TufA sequence of Caulerpa species from Bintan Island shared 100\% similarity with C. oligophylla (FM956043), which was previously known as $C$. racemosa var. lamourouxii (Belton et al., 2014) and 99\% similarity with $C$. racemosa (FM956051) in the GenBank database, which is previously sequenced from Thousand Islands, Java Sea, Indonesia. In Jepara, Caulerpa species presented 100\% similarity with C. oligophylla (FM956043) from Thousand Islands, Java Sea, Indonesia, and 100\% similarity with $C$. cylindracea (JN817677) from Montgomery reef, Western Australia, Australia, which was previously known as $C$. racemosa var. cylindracea (Belton et al., 2014). Three different species of Caulerpa were found in Osi Island. TufA sequence of Caulerpa from Osi Island showed 100\% similarity with C. oligophylla (FM956043) from Thousand Islands, Java Sea, Indonesia; $100 \%$ similarity with $C$. macra (KF256089), which was previously known as $C$. racemosa var. macra (Belton et al., 2014) and 99\% similarity with $C$. racemosa (FM956052), both sequenced from Berau Delta, East Kalimantan, Indonesia. All samples sequenced from Takalar had $100 \%$ similarity with C. cylindracea (JN817677) from Montgomery reef, Western Australia, Australia (Sauvage et al., 2013; Belton et al., 2014).
The maximum-likelihood tree was used for the molecular evolution models produced a phylogeny with a log-likelihood score of -1879.91 . There are six clades of Caulerpa found based on the phylogenetic tree using the maximum-likelihood method (Figure 2). The phylogram clustered all tufA sequence of $C$. cylindracea in clade one, including Takalar and Jepara samples. Two samples from Osi Island clustered in clade two with other sequences of $C$. macra from Genbank. Clade three (C. oligophylla) consisted of samples from Bintan Island, Jepara, and Osi Island. The population of $C$. racemosa from Osi Island and Bintan Island was clustered in clade five. Meanwhile, clade four clustered tufA sequence of $C$. macrodisca and clade six of $C$. chemnitzia consisted only sequences from the Genbank (Figure 2).

Two different species of Caulerpa (C. chemnitzia and $C$. macrodisca) which were previously reported in three other sites in Indonesia (Thousand Island, Java Sea; Berau Delta, East Kalimantan, and West Papua) (Sauvage al., 2013; Belton et al., 2014) were not found in this study. This study thus reports of the existence of C. cylindracea in Takalar and Jepara, Indonesia for the first time. Even though the location is distant geographically, C. cylindracea from Takalar and Jepara had high similarity with $C$. cylindracea from Australia. Domingues, Hilsdorf, Shivji, Hazin, and Gadig (2017) found that there was no relationship between genetic distance and geographic distance. The ability of seaweed to drift along with ocean currents is one of the essential characteristics that allows the seaweed to spread over long distances resulting in complex biogeographic patterns (De Bruyn, Martin, \& Lefeuvre, 2014).

Information about the existence of $C$. cylindracea in Indonesia is essential. C. cylindracea has been recently identified as an independent species (Belton et al., 2014). It was formerly recognized as $C$. racemosa var. cylindracea (Sonder) Verlaque, Huisman \& Boudouresque (Verlaque et al., 2003). Caulerpa cylindracea was classified as invasive species in several sites in the world, such as in Canary Island (Sangil \& Juan, 2020), Algeria (Boumediene \& Lotfi, 2019), and especially in the Mediterranean (Bernardeau-Esteller et al., 2020; Rizzo, Pusceddu, Bianchelli, \& Fraschetti, 2020; Sinopoli et al., 2020). C. cylindracea and $C$. taxifolia were among the fastest spread rates of marine bio-invasions (Ruitton et al., 2005), and notable for $C$. cylindracea, and it exhibits an impressive and constant expansion from the beginning of its first appearance in the Mediterranean (Montefalcone, Morri, Parravicini, $\&$ Bianchi, 2015). This seaweed can have a negative impact on the marine environment because it can $(C$. 
Tabel 1. Identification of Caulerpa racemosa samples using tufA primer

\begin{tabular}{|c|c|c|c|c|c|c|c|}
\hline \multirow{2}{*}{$\begin{array}{c}\text { No } \\
1\end{array}$} & \multirow{2}{*}{$\begin{array}{c}\text { Location } \\
\text { Bintan Island }\end{array}$} & \multirow{2}{*}{$\begin{array}{c}\begin{array}{c}\text { Sample } \\
\text { Name }\end{array} \\
\text { Bintan } 01\end{array}$} & \multicolumn{2}{|c|}{ GPS Coordinates } & \multirow{2}{*}{$\begin{array}{c}\text { Date of Collection } \\
\text { September } 2019\end{array}$} & \multirow{2}{*}{$\begin{array}{c}\text { Sample Identification } \\
\text { Caulerpa oligophylla }\end{array}$} & \multirow{2}{*}{$\begin{array}{c}\begin{array}{c}\text { Genbank Accession } \\
\text { number }\end{array} \\
\text { FM956043 }\end{array}$} \\
\hline & & & $0^{\circ} 52 ' 28.58 "$ & $\mathrm{~N}$ & & & \\
\hline & & & $104^{\circ} 25^{\prime} 3.37^{\prime \prime}$ & $\mathrm{E}$ & & & \\
\hline \multirow[t]{2}{*}{2} & Bintan Island & Bintan 02 & 052'26.62" & $\mathrm{N}$ & September 2019 & Caulerpa racemosa & FM956051 \\
\hline & & & $104^{\circ} 25^{\prime} 3.08^{\prime \prime}$ & $\mathrm{E}$ & & & \\
\hline \multirow[t]{2}{*}{3} & Bintan Island & Bintan 03 & 0॰52'24.59" & $\mathrm{N}$ & September 2019 & Caulerpa oligophylla & FM956043 \\
\hline & & & $104^{\circ} 25^{\prime} 6.26^{\prime \prime}$ & $\mathrm{E}$ & & & \\
\hline \multirow[t]{2}{*}{4} & Bintan Island & Bintan 04 & 0॰52'25.52" & N & September 2019 & Caulerpa oligophylla & FM956043 \\
\hline & & & $104^{\circ} 25^{\prime} 7.68^{\prime \prime}$ & E & & & \\
\hline \multirow[t]{2}{*}{5} & Bintan Island & Bintan 05 & 052'26.80" & $\mathrm{N}$ & September 2019 & Caulerpa racemosa & FM956051 \\
\hline & & & $104^{\circ} 25^{\prime} 8.11^{\prime \prime}$ & E & & & \\
\hline \multirow[t]{2}{*}{6} & Jepara & Jepara 01 & 0636'49.36" & $\mathrm{s}$ & October 2018 & Caulerpa oligophylla & FM956043 \\
\hline & & & $110^{\circ} 38^{\prime} 10.03^{\prime \prime}$ & $E$ & & & \\
\hline \multirow[t]{2}{*}{7} & Jepara & Jepara 02 & 0636'51.99" & $\mathrm{s}$ & October 2018 & Caulerpa oligophylla & FM956043 \\
\hline & & & $110 \div 38 ' 04.10^{\prime \prime}$ & E & & & \\
\hline \multirow[t]{2}{*}{8} & Jepara & Jepara 03 & 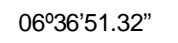 & S & October 2018 & Caulerpa cylindracea & JN817677 \\
\hline & & & $110^{\circ} 38^{\prime} 04.22^{\prime \prime}$ & $\mathrm{E}$ & & & \\
\hline \multirow[t]{2}{*}{9} & Jepara & Jepara 04 & 0636'49.73" & S & October 2018 & Caulerpa oligophylla & FM956043 \\
\hline & & & $110^{\circ} 38^{\prime} 05.15^{\prime \prime}$ & E & & & \\
\hline \multirow[t]{2}{*}{10} & Jepara & Jepara 05 & 0636'50.91" & $S$ & October 2018 & Caulerpa oligophylla & FM956043 \\
\hline & & & $110^{\circ} 38^{\prime} 04.63^{\prime \prime}$ & E & & & \\
\hline \multirow[t]{2}{*}{11} & Osi Island & Osi 01 & 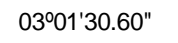 & S & December 2018 & Caulerpa racemosa & FM956052 \\
\hline & & & 1280ㄴ'39.90" & E & & & \\
\hline \multirow[t]{2}{*}{12} & Osi Island & Osi 02 & 030ำ'48.55" & $\mathrm{s}$ & December 2018 & Caulerpa macra & KF256089 \\
\hline & & & $128^{\circ} 05^{\prime} 31.45^{\prime \prime}$ & E & & & \\
\hline \multirow[t]{2}{*}{13} & Osi Island & Osi 03 & 030ํ'48.07" & S & December 2018 & Caulerpa oligophylla & FM956043 \\
\hline & & & 12805'31.49" & E & & & \\
\hline \multirow[t]{2}{*}{14} & Osi Island & Osi 04 & 0301'47.62" & $\mathrm{s}$ & December 2018 & Caulerpa macra & KF256089 \\
\hline & & & 1280'31.44" & E & & & \\
\hline \multirow[t]{2}{*}{15} & Osi Island & Osi 05 & 0301'31.55" & $\mathrm{s}$ & December 2018 & Caulerpa oligophylla & FM956043 \\
\hline & & & $128^{\circ} 04^{\prime} 39.76^{\prime \prime}$ & E & & & \\
\hline \multirow[t]{2}{*}{16} & Takalar & Takalar 01 & 053'1.37" & $\mathrm{s}$ & November 2018 & Caulerpa cylindracea & JN817677 \\
\hline & & & 11927'54.33" & E & & & \\
\hline \multirow[t]{2}{*}{17} & Takalar & Takalar 02 & 0535'1.07" & $\mathrm{s}$ & November 2018 & Caulerpa cylindracea & JN817677 \\
\hline & & & 11927'55.23" & E & & & \\
\hline \multirow[t]{2}{*}{18} & Takalar & Takalar 03 & 053' $3.47 "$ & $S$ & November 2018 & Caulerpa cylindracea & JN817677 \\
\hline & & & $119027 ' 53.48 "$ & E & & & \\
\hline \multirow[t]{2}{*}{19} & Takalar & Takalar 04 & 053'‥58" & $S$ & November 2018 & Caulerpa cylindracea & JN817677 \\
\hline & & & 119²7'54.00" & E & & & \\
\hline 20 & Takalar & Takalar 05 & 0535'0.81" & $\mathrm{s}$ & November 2018 & Caulerpa cylindracea & JN817677 \\
\hline & & & $104^{\circ} 25^{\prime} 8.11 "$ & $\mathrm{E}$ & & & \\
\hline
\end{tabular}

change the structure of marine communities (Sangil \& Juan, 2020). Despite this negative impact on the environment, the $C$. cylindracea found in Takalar became one of the seaweed commodities developed by the community. Local people utilized this type of seaweed not only for local consumption but also for economic values. The community cultured this seaweed in a pond and marketed it locally and overseas (Perryman, Lapong, Mustafa, Sabang, \& Rimmer, 2017). The molecular identification of $C$. cylindracea can improve the utilization of this kind of seaweed by searching the best characteristic of $C$. cylindracea for economic value through tissue culture.

\section{Haplotype Network}

Caulerpa species in four different sites showed a slight variation in the tufA gene with only four haplotypes recorded, and each haplotype corresponded to various other species. Haplotype one, which corresponded to $C$. oligophylla, was dominant and 


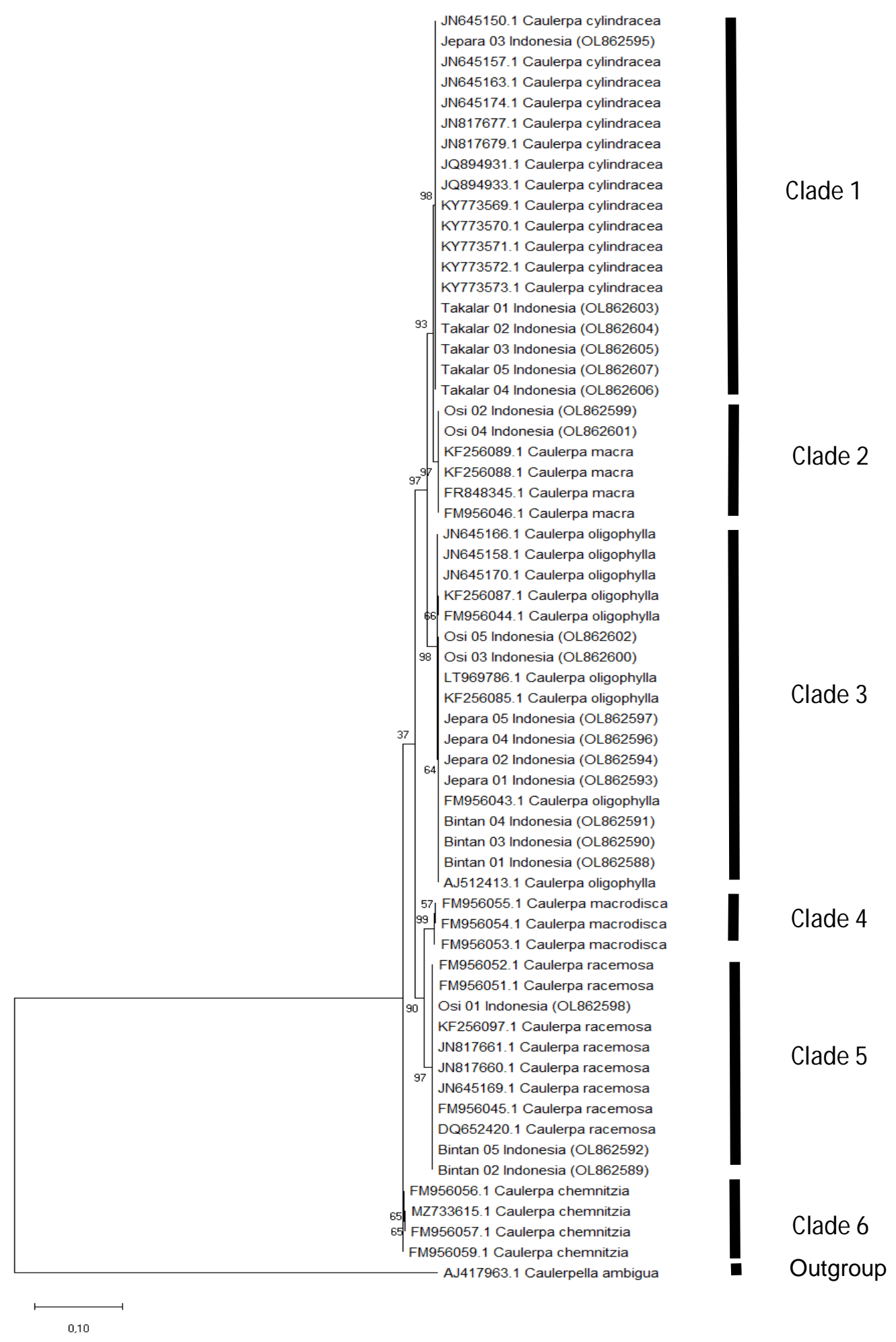

Figure 2. Maximum-livelihood phylogeny of partial DNA sequences of C. racemosa samples from four sites plus identified sequences from Genbank. Accession numbers are given.

cylindracea) were found in two different sites. Two samples of Caulerpa from Osi Island formed a distinct group characterized by haplotype four corresponding with $C$. macra. Osi Island had the most diverse species of Caulerpa (three species), while Takalar had a low genetic variation with only one species of Caulerpa. The haplotype network in four locations and the species distribution map can be seen in Figures 3 and 4. 


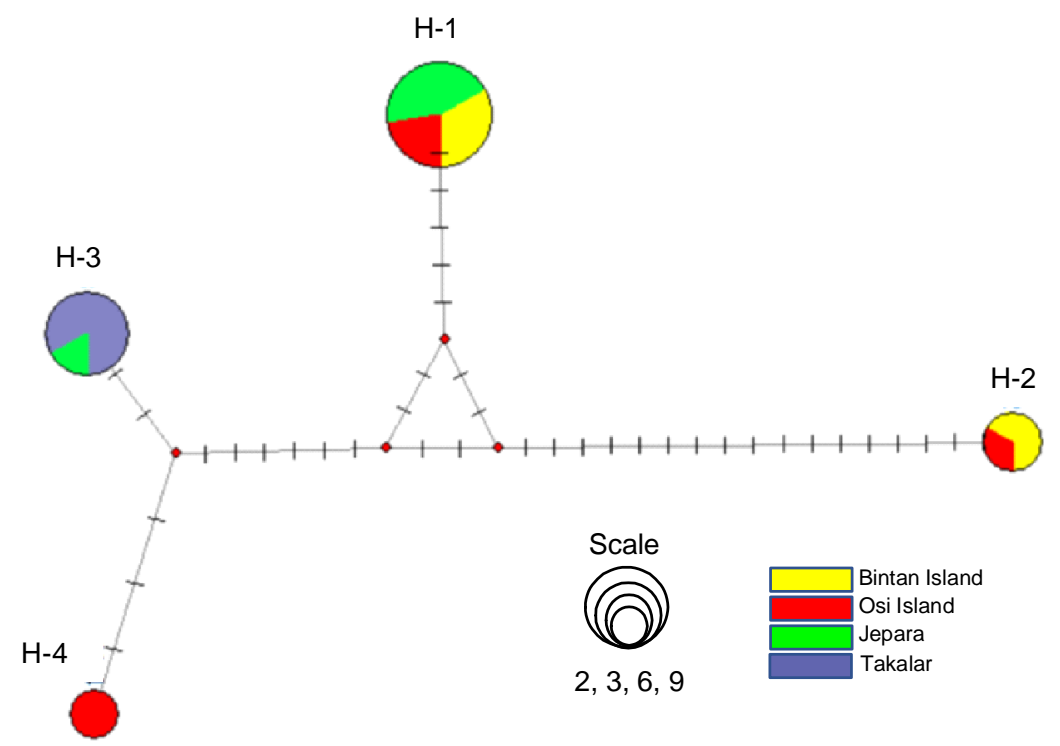

Figure 3. Haplotype network of C. racemosa showing the distribution of the haplotypes in four geographical regions in this study (Note: The scale of the diameter of the circle correspond with the number of species found).

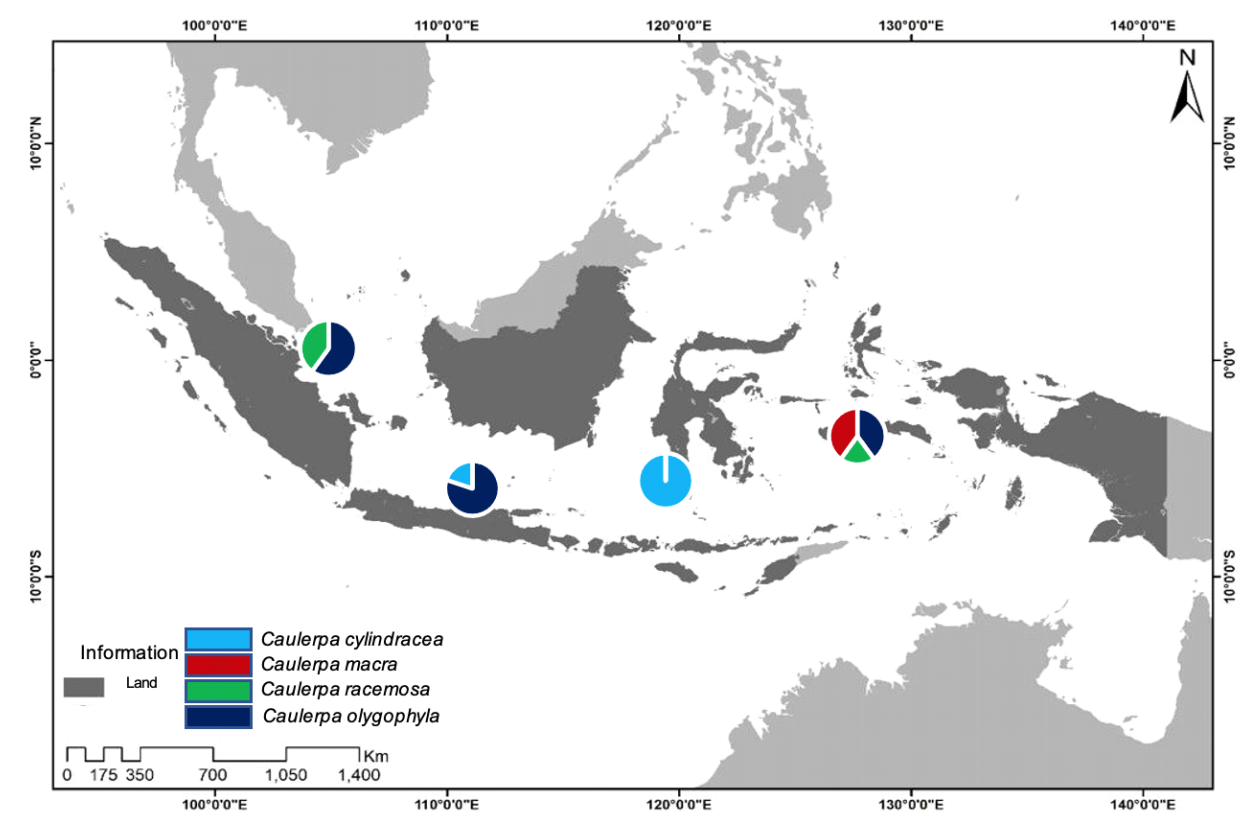

Figure 4. Species distribution of C. racemosa across the population in four geographical regions in this study.

Some of the population of Caulerpa, for example, C. oligophylla in Bintan, Jepara, and Osi Island, had a similar haplotype composition. This relationship was suspected due to their dispersal capacity supported by the movement of the current. One of the factors affecting algal phylogeography is long-distance dispersal, which can lead to widely distributed species and can be anthropogenic or natural (Sherwood \& Zuccarello, 2016). Previous studies have shown that dispersal capacity by fragmentation of $C$. taxifolia (Checcerelli \& Chinelli, 1999; Rushdi et al., 2020) and
C. racemosa (Checcerelli \& Piazzi, 2001) was likely to contribute to the spread of those algae in the Mediterranean Sea. The haplotype of $C$. cylindracea in Takalar was relatively homogenous, which was dominated by haplotype 3 . This condition may be influenced by the Indonesian Through Flow (ITF). Indonesian Through Flow (ITF) plays an essential role in marine biogeography in the Wallacea line region, namely the Makassar Strait, and can be a significant barrier to species dispersal patterns (Hall, 2009; Chasani, 2017). 


\section{Conclusion}

Identification of $C$. racemosa variant samples using the tufA gene in this study found four different Caulerpa species: C. racemosa, C. macra, C. oligophylla, and C. cylindracea. The genetic diversity of Caulerpa species in four other locations (Bintan Island, Jepara, Osi Island, and Takalar) showed a little haplotype diversity. Caulerpa species in all areas consisted of four haplotypes, and each haplotype corresponded to a different species. This study has revealed the first record of $C$. cylindracea found in Indonesia.

\section{References}

Atmadja, W.S. \& Prud'homme van Reine, W.F. (2014). Checklist of the seaweed species biodiversity of Indonesia with their distribution and classification: green algae (Chlorophyta) and brown algae (Phaeophyceae, Ochrophyta). pp. [2], i-v, 1-59. Leiden \& Indonesia: Naturalis Biodiversity Centre, Indonesian Institute of Sciences (LIPI).

Baleta, F. N., \& Nalleb, J. P. (2016). Species composition, abundance and diversity of seaweeds along the intertidal zone of Nangaramoan, San Vicente, Sta. Ana, Cagayan, Philippines. AACL Bioflux, 9(2), 250-259.

Bandelt, H.J., Forster, P., \& Rohl, A. (1999). Median-joining networks for inferring intraspecific phylogenies. Molecular Biology and Evolution, 16:37-48. doi: 10.1093/ oxfordjournals.molbev.a026036

Belton, G.S., Prud'homme Van Reine, W.F., Huisman, J.M., Draisma, S.G.A., \& Gurgel, C.F.D. (2014). Resolving phenotypic plasticity and species designation in the morphologically challenging Caulerpa racemosa-peltata complex (Chlorophyta, Caulerpaceae). Journal of Phycology 50(1):32-54. doi: 10.1111/jpy.12132

Belton, G.S., Draisma, S.G.A., Prud'homme van Reine, W.F., Huisman, J.M., \& Gurgel, J.F.D. (2019). A taxonomic reassessment of Caulerpa (Chlorophyta, Caulerpaceae) in southern Australia, based on tufA and $r b c \mathrm{~L}$ sequence data. Phycologia, 52(1): 6-13. doi: 10.1080/00318884.2018. 1542851

Bernardeau-Esteller, J., Marín-Guirao, L., Sandoval-Gil, J. M., García-Muñoz, R., Ramos-Segura, A., \& Ruiz, J. M. (2020). Evidence for the long-term resistance of Posidonia oceanica meadows to Caulerpa cylindracea invasion. Aquatic Botany, 160. doi:10.1016/j.aquabot.2019.103167

Boumediene, HK \& Lotfi, BT (2019). First record of invasive green algae Caulerpa racemosa var. cylindracea in Oran Bay (Western Algeria). Indian Journal of Geo-Marine Sciences. 48(3):335-342.

Castresana, J. (2000). Selection of conserved blocks from multiple alignments for their use in phylogenetic analysis. Molecular Biology and Evolution. 17(4):540-552. doi:10.1093/oxfordjournals.molbev.a026334

Ceccherelli, G. \& Cinelli, F. (1999). The role of vegetative fragmentation in dispersal of the invasive alga Caulerpa taxifolia in the Mediterranean. Marine Ecology Progress Series. 182: 299-303. doi: 10.3354/meps 182299
Ceccherelli, G. \& Piazzi, L. (2001). Dispersal of Caulerpa racemosa Fragments in the Mediterranean: Lack of Detachment Time Effect on Establishment. Botanica Marina. 44: 209-213. doi: 10.1515/BOT.2001.027

Chasani, A.R. (2017). Phylogeography of Gracilaria salicornia (C. Agardh) E. Y. Dawson and Hypnea pannosa J. Agardh in the Wallacea Region. Thesis. Northern Territory (AU): Charles Darwin University.

Darmawan, M., Fajarningsih, N.D., Sihono, \& Irianto, H.E. (2020). Caulerpa: Ecology, Nutraceutical, and Pharmaceutical Potential. In N. M Nathani et al. (Eds.), Marine Niche: Applications in Pharmaceutical Sciences. pp. 299-318: Springer. doi:10.1007/978-981-15-5017-1_17

De Bruyn, A., Martin, D.P., \& Lefeuvre, P. (2014). Phylogenetic reconstruction methods: an overview. Molecular Plant Taxonomy. 1115:257-277. doi:10.1007/978-1-62703-7679_13

de Senerpont Dormis, L.N., Fama, P., Bartlet, A.J., Prud'homme Van Reine, W.F., Espinosa, C.A., \& Trono,G.C. (2003). Defining taxon boundaries in members of the morphologically and genetically plastic genus Caulerpa (Caulerpales, Chlorophyta). Journal of Phycology 39(6), 1019-1037. doi: 10.1111/j.0022-3646.2003.02-203.x

Domingues, R.R., Hilsdorf, A.W., Shivji, M.M., Hazin, F.V., \& Gadig, O.B. (2017). Effects of the pleistocene on the mitochondrial population genetic structure and demographic history of the silky shark (Carcharhinus falciformis) in the western Atlantic Ocean. Reviews in Fish Biology and Fisheries, 28(1): 213-227. doi: 10.1007/s11160-017-9504$\mathrm{z}$

Draisma, S.G.A., Prud'homme Van Reine, W.F., Sauvage, T., Belton, G.S., Gurgel, C.F.D., Lim, P.E., \& Phang, S.M. (2014). A reassessment of the infra-generic classification of the genus Caulerpa (Caulerpaceae, Chlorophyta) inferred from a time-calibrated molecular phylogeny. Journal of Phycology. 50(6):1020-1034. doi: 10.1111/jpy.12231

Dumilag, R.V., Gallardo, W.G.M., Garcia, C.P.C., You, Y.E., Chaves, A.K.G., \& Agahan, L. (2018). Phenotypic and mtDNA variation in Philippine Kappaphycus cottonii (Gigartinales, Rhodophyta). Mitochondrial DNA Part A: DNA Mapping, Sequencing, and Analysis, 29(6): 951-963. doi:10.1080/24701394.2017.1398745

Dumilag, R.V., Aguinaldo, Z.Z.A., Alcoriza, V.A.M., Balucanag, M.P.S.B., Dulalia, A.R.T., \& Sayasa, A.R. (2019). DNA barcodes of Caulerpa species (Caulerpaceae, chlorophyta) from the Northern Philippines. Philippine Journal of Science. 148(2):337-347.

Guiry, M.D. \& Guiry (2021). AlgaeBase. Worldwide electronic publication, National University of Ireland, Galway. Retrieved from https://www.algaebase.org/search/genus/ detail/?genus_id =32944\&-session=abv4:AC1F0 64011 bad 09F7EOL2628A48A. Accessed on 12 June 2021.

Estrada, J. L., Bautista, N. S., \& Dionisio-Sese, M. L. (2020). Morphological variation of two common sea grapes (Caulerpa lentillifera and caulerpa racemosa) from selected regions in the Philippines. Biodiversitas, 21(5), 1823-1832. doi:10.13057/biodiv/d210508.

Fama, P., Procaccini, G., Olsen, J., \& Stam, W. (2000). High levels of intra- and inter-individual polymorphism in the 
rDNA ITS1 of Caulerpa racemosa (Chlorophyta). European Journal of Phycology 35(4):349-356. doi: 10.1080/0967026001000173595

Hall, R. (2009). Southeast Asia's changing paleogeography. Blumea. 54:148-161. doi:10.3767/000651909X475941

Kazi, M.A., Reddy, C.R.K., \& Jha, B. (2013). Molecular phylogeny and barcoding of Caulerpa (bryopsidales) based on the tufA, $r b c \mathrm{~L}, 18 \mathrm{~S}$ rDNA and ITS rDNA genes. PLoS One, 8(12):1-13. doi:10.1371/journal.pone.0082438

Manas, H.M., Desmukhe, G., Venkateshwarlu, G., Chakraborty, S., Jaiswar, A.K., Mugaonkar, P.H., \& Dar, S.A. (2015). Morphological Comparison of different Caulerpa J. V. Lamouroux species along Maharashtra and Gujarat coast, India. Indian Journal of Geo-Marine Sciences, 44(5). doi:10.35799/jis.18.2.2018.20821

Ministry of Marine Affairs and Fisheries (2017). KKP Kembangkan Lawi-lawi untuk Ekspor. [Internet]. Retrieved from http://www.djpb.kkp.go.id/index.php/arsip/c/509/kkpkembangkan-lawi-lawi-untuk-tembus-ekspor/ ?category_id=; Accessed on 13 July 2021.

Montefalcone, M., Morri, C., Parravicini, V., \& Bianchi, C. N. (2015). A tale of two invaders: divergent spreading kinetics of the alien green algae Caulerpa taxifolia and Caulerpa cylindracea. Biological Invasions, 17(9):2717-2728. doi:10.1007/s10530-015-0908-1

Nei, M. \& Kumar, S. (2000). Molecular Evolution and PhylogeneticsI. Oxford University Press. New York.

Ningrum, A.M., \& Chasani, A.R. (2021). Numerical phenetic and phylogenetic relationships in silico among brown seaweeds (Phaeophyceae) from Gunung Kidul, Yogyakarta, Indonesia. Biodiversitas, 22(6): 3057-3064. doi:10.13057/ biodiv/d220607

Perryman, S.E., Lapong, I., Mustafa, A., Sabang, R., \& Rimmer, M.A. (2017). Potential of metal contamination to affect the food safety of seaweed (Caulerpa spp.) cultured in coastal ponds in Sulawesi, Indonesia. Aquaculture Reports, 5:2733. doi:10.1016/j.aqrep.2016.12.002

Rizzo, L., Pusceddu, A., Bianchelli, S., \& Fraschetti, S. (2020). Potentially combined effect of the invasive seaweed Caulerpa cylindracea (Sonder) and sediment deposition rates on organic matter and meiofaunal assemblages. Marine Environmental Research, 159. doi:10.1016/j.marenvres. 2020.104966

Ruitton, S., Javel, F., Culioli, J.M., Meinesz, A., Pergent, G., \& Verlaque, M. (2005). First assessment of the Caulerpa racemosa (Caulerpales, Chlorophyta) invasion along the French Mediterranean coast. Marine Pollution Bulletin 50:1061-1068. doi:10.1016/j.marpolbul.2005.04.009

Rushdi, M. I., Abdel-Rahman, I. A. M., Attia, E. Z., Abdelraheem, W. M., Saber, H., Madkour, H. A., Amin, E., Hassan, H. M., \& Abdelmohsen, U. R. (2020). A review on the diversity, chemical and pharmacological potential of the green algae genus Caulerpa. South African Journal of Botany, 132, 226 241. doi:10.1016/j.sajb.2020.04.031

Sangil, C., \& Juan, A. P. S. (2020). Spread of Caulerpa cylindracea impacts: The colonization of Atlantic intertidal communities. Regional Studies in Marine Science. 34. doi:10.1016/j.rsma.2019.100989

Sauvage, T., Payri, C., Draisma, S.G.A., Prud'homme van Reine, W.F., Verbruggen, H., Belton, G.S., ... Fredericq, S. (2013). Molecular diversity of the Caulerpa racemosa-Caulerpa peltata complex (Caulerpaceae, Bryopsidales) in New Caledonia, with new Australasian records for C. racemosa var. cylindracea. Phycologia, 52(1):6-13. doi: 10.2216/11116.1

Sauvage, T., Wynne, M.J., Paul, V.J., Fredericq, S. (2014). Morphological and molecular clarification of the enigmatic Caulerpa floridana W.R. Taylor (Chlorophyta, Bryopsidales) from the Dry Tortugas, Florida. European Journal of Phycology, 49(3):370-383. doi: 10.1080/ 09670262.2014.947330

Sherwood, A.R., \& Zuccarello, G.C. (2016). Phylogeography of tropical Pacific marine algae. In Z.-M. Hu, \& C. Fraser (Eìds.), Seaweed Phylogeography. pp. 211-226: Springer. doi: 10.1007/978-94-017-7534-2_8

Sinopoli, M., Allegra, A., Andaloro, F., Consoli, P., Esposito, V., Falautano, M. ... Castriota, L. (2020). Assessing the effect of the alien seaweed Caulerpa cylindracea on infralittoral rocky benthic invertebrate community: Evidence from a Mediterranean Marine Protected Area. Regional Studies in Marine Science, 38. doi:10.1016/j.rsma. 2020.101372

Tamura, K., Stecher, G., Peterson, D., Filipski, A., \& Kumar, S. (2013). MEGA6: molecular evolutionary genetics analysis version 6.0. Molecular Biology and Evolution. 30:27252729. doi: 10.1093/molbev/mst197

Thompson, J.D., Higgins, D.G., \& Gibson, T.J. (1994). CLUSTAL W: Improving the sensitivity of progressive multiple sequence alignment through sequence weighting, position-specific gap penalties and weight matrix choice. Nucleic Acids Research, 22(22):4673-4680. doi: 10.1093/ nar/22.22.4673

Wynne, M., Verbruggen, H., \& Angel, D. (2009). The recognition of Caulerpa integerrima (Zanardini) comb. et stat. nov. (Bryopsidales, Chlorophyta) from the Red Sea. Phycologia, 48(4):291-301. doi: 10.2216/08-78.1

Zubia, M., Draisma, S. G. A., Morrissey, K. L., Varela-Álvarez, E., \& De Clerck, O. (2020). Concise review of the genus Caulerpa J.V. Lamouroux. Journal of Applied Phycology, 32(1), 23-39. doi:10.1007/s10811-019-01868-9

Zuccarello, G.C., \& Lokhorst, G.M. (2005). Molecular phylogeny of the genus Tribonema (Xanthophyceae) using $r b c \mathrm{~L}$ gen sequence data: monophyly of morphologically simple algal species. Phycologia, 44(4):384-392. doi: 10.2216/0031-8884(2005)44[384:MPOTGT]2.0.CO;2

Zuccarello, G.C. \& Paul, N.A. (2019). A beginner's guide to molecular identification of seaweed. Squalen Bulletin of Marine and Fisheries Postharvest and Biotechnology, 14(1):43-53. doi: 10.15578/squalen.v14i1.384

Žuljeviæ, A., Antoliæ, B., Onofri, V. (2003). First record of Caulerpa racemosa (Caulerpales: Chlorophyta) in the Adriatic Sea. J. Mar. Biol. Assoc. United Kingdom. 83(4): 711-712. doi: 10.1017/s0025315403007689h 